\title{
ARTICLE \\ Molecular cloning, tissue distribution and ontogenetic expression of growth hormone in cobia, Rachycentron canadum
}

\author{
Clonación molecular, distribución tisular y expresión ontogenética de la hormona \\ de crecimiento en la cobia, Rachycentron canadum
}

\section{Leonardo Ibarra-Castro ${ }^{1,3^{*}}$, Kenneth A. Webb Jr. ${ }^{1,2}$ and G. Joan Holt ${ }^{1}$}

\begin{abstract}
${ }^{1}$ The University of Texas at Austin Marine Science Institute, Fisheries and Mariculture Laboratory, 750 Channel View Drive, Port Aransas, TX 78373, United States of America

${ }^{2}$ NOAA Northwest Fisheries Science Center, 2725 Montlake Blvd E, Seattle, WA 98112, United States of America

${ }^{3}$ Laboratory of Reproduction and Marine Finfish Hatchery, Centro de Investigación en Alimentación y Desarrollo (CIAD), A. C., Unidad Mazatlán, Avenida Sábalo Cerritos S/N, Mazatlán, C.P. 82000, A.P. 711, Sinaloa, México. *leonardo.ibarra@ciad.mx, leobeis@hotmail.com
\end{abstract}

\begin{abstract}
Resumen.- A nivel mundial, el crecimiento de la acuicultura marina está limitado por una serie de factores. Uno de los más importantes es el desarrollo de protocolos de larvicultura para producir un número adecuado de juveniles para abastecer los sistemas de engorda a un costo conveniente. Con el fin de desarrollar una herramienta para evaluar el estado nutricional de las larvas de cobia, se ha clonado y secuenciado la Hormona de Crecimiento (GH) de la hipófisis de peces adultos, y se examinó la expresión ontogenética en muestras de embriones y larvas por GPCR, así como la distribución en los tejidos en animales adultos silvestres mediante RT-PCR. La secuencia de GH de cobia mostró similitud con la secuencia de GH de Coryphaena hippurus (mahi mahi), Seriola dumerili (mayor medregal) y Seriola quinqueradiata (jurel). La expresión del gen GH se estudió en 18 tejidos diferentes, pero sólo se detectó en la hipófisis, los ojos, branquias y músculo rojo. Los niveles de expresión fueron bajos en los embriones y larvas, pero justo antes de la primera alimentación, la expresión de genes se incrementó dramáticamente ( 1000 veces) y se mantuvieron altos durante el resto del período de recolección de muestras ( $300 \mathrm{~h}$ después de la fecundación). Este patrón de expresión es similar al observado en otras especies de peces marinos de aguas templadas con rápido crecimiento y se remarca con un rápido crecimiento somático que inicia con la primera alimentación en cobia.
\end{abstract}

Palabras clave: Cobia, hormona de crecimiento, larvas, expresión ontogénica

Abstract.- Worldwide, the growth of marine aquaculture is limited by a number of factors. One of the most important is the development of larviculture protocols to produce adequate numbers of juveniles to stock grow-out systems at a convenient cost. In order to develop a tool to assess the nutritional status of cobia larvae, we have cloned and sequenced the Growth Hormone (GH) from the pituitary gland of adult fish, and examined the ontogenetic expression in embryonic and larval specimens by qPCR, as well as tissue distribution in wild adult animals by RT-PCR. The cobia GH sequence showed similarity to the GH sequence of Coryphaena hippurus (mahi mahi), Seriola dumerili (Greater amberjack) and Seriola quinqueradiata (Yellowtail). GH gene expression was studied in 18 different tissues, but was only detected in the pituitary gland, eyes, gill and red muscle. Expression levels were very low in embryos and in early larvae but just before the first feeding, gene expression increased dramatically ( 1000 fold) and remained high for the rest of the collection period (to $300 \mathrm{~h}$ post fertilization). This pattern of expression is similar to that seen in other rapidly growing temperate marine fish and underscores the rapid somatic growth that begins with the onset of feeding in cobia.

Key words: Cobia, growth hormone, molecular cloning, larvae, ontogenetic expression

\section{INTRODUCTION}

Growth rate is of great economic importance in the culture of food animals because rapid growth typically equates to the rapid turnover of production. Cobia Rachycentron canadum (Linnaeus, 1766) is a rapid-growing fish reaching large adult size in a year and a half or less; it commands a good price in the world market, and is easily adaptable to captivity and domestication (Chou et al. 2001, Liao et al. 2004). In the last decade, cobia has been subject to intensive research in areas such as nutrition (Chou et al. 2001, Faulk \& Holt 2003, Wang et al. 2005, Craig et al. 2006, Zhou et al. 2006) and larval rearing (Faulk \& Holt 2005, 2006; Hitzfelder et al. 2006, Resley et al. 2006, Benetti et al. 2008), however as cobia is still a relatively new and emerging species for aquaculture, there is the need for more investigation in larviculture and weaning 
with microparticulate diets (Holt et al. 2011). Current efforts to raise larval cobia have been relatively successful, but it remains difficult to assess the success of different rearing regimes without long replicated growth and survival trials. There are a number of tools available to assess larval feeding such as gut content analysis or fluorescent labeling of feeds, but these methods do not show whether the larvae are capable of digesting the provided feeds. The development of a tool to assess the nutritional status of larvae within a relatively short period of time would allow the manufacture of diets and weaning strategies to be evaluated much more quickly and would lead to a more rapid development of cobia larviculture.

One potential tool to assess nutritional status and growth in larval cobia is to measure expression of a regulatory hormone which indicates that the larva is currently undergoing somatic growth. A likely candidate for this type of measurement is the hormone somatotrophin commonly known as Growth Hormone (GH). The importance of $\mathrm{GH}$ as a growth-promoting agent has long been recognized, as has its potential application in the fish farming industry (Li et al. 2005). GH is produced by the pituitary and is regulated by 2 hypothalamic neuropeptides, the $\mathrm{GH}-$ releasing factor (positive regulator) and the inhibitory somatostatin (negative regulator) (Bolander 2004) but it is important to understand that the GH secretion in fish is a multifactorial process (Canosa et al. 2007). GH is known to have direct metabolic actions leading to the growth of muscle tissue as well as direct and indirect actions regulating skeletal growth (Bolander 2004). As in other marine fish, larval and early juvenile cobia utilize a large proportion of consumed calories for growth (Watson \& Holt 2010) and it is therefore likely that GH will be rapidly responsive to changes in the nutritional status. At this time, there is no information regarding the time of GH system activation in larval cobia, thus, the goal of the present study was to obtain $\mathrm{GH}$ sequencing and examine the ontogenetic expression of GH in cobia embryo and larvae, in order to determine its potential utility as a tool in assessing nutrients and nutritional status of cobia larvae.

\section{Materials AND MeTHODS}

\section{SPECIMENS}

All collections and analyses were performed at the University of Texas at Austin's Marine Science Institute in the Fisheries and Mariculture Laboratory (FAML). Larvae and juveniles were obtained from 2 different groups of cobia broodstock at FAML (except noted otherwise), and were raised according to standard laboratory methods (Faulk \& Holt 2005, Faulk et al. 2007), except that newly-hatched Artemia nauplii were not used. All adult fish were collected from the wild by local fishermen.
Juvenile cobia used for tissue distribution studies were raised from eggs at FAML and maintained in $5500 \mathrm{~L}$ tanks for 9 months. Culture temperature and salinity varied through the course of the culture period and ranged from 15 to $28^{\circ} \mathrm{C}$ and 27 to 35 , respectively. These temperatures simulate the natural temperature; a fluctuation experienced by cobia in these 2 locations and was used to induce spawning. Embryos and larvae used for the ontogenetic analysis came from either 2 of the broodstock tanks at FAML or from the Aquaculture Center of the Florida Keys (ACFK) courtesy of Dr. Daniel Benetti. Eggs were placed directly into cylindrical fiberglass tanks $(500 \mathrm{~L}$ total volume) the day after spawning except for the batch of eggs received from ACFK. These eggs were placed into a large incubator tank (1300L) and $48 \mathrm{~h}$ after hatch, 4000 larvae (10/L/tank) were moved by hand into each of 4 tanks in the culture system. Tanks within the culture system were connected to a common $1-\mathrm{m}^{3}$ berglass lter box containing plastic biolter media. Water in the system was recirculated within the filter box and the tanks after passing through a sand lter containing Lanpac bio-media (Lantec Products, Inc., Agoura Hill, CA, USA). Water levels in the tanks were maintained at $400 \mathrm{~L}$ through the use of an internal standpipe. Water flow in each tank was set at $1 \mathrm{~L} \mathrm{~min}^{-1}$ once the eggs were placed in the tank and was increased to $3 \mathrm{~L} \mathrm{~min}^{-1}$ after feeding began at 3 days post hatch (DPH). Supplemental aeration was provided through air diffuser tubing forming a ring around the base of the internal standpipe. The larvae were fed rotifers (Brachionus plicatilis) enriched with Algamac 3000 (Aquafauna Bio-Marine, Hawthorne, California, USA) from 3 to $10 \mathrm{DPH}$ and enriched Artemia nauplii from 10 to $12 \mathrm{DPH}$.

\section{MoleCular ClONING}

Cloning was performed using the pituitary gland from 5 different adult fish. Heads were collected from a local fish processor and the pituitary was immediately removed, frozen, and stored at $-80^{\circ} \mathrm{C}$ until use. Total RNA was extracted using TriReagent ${ }^{\circledR}$ RT (Molecular Research Center, Cincinnati, OH, USA) according to the manufacturer's recommendations. RNA concentration was determined spectrophotometrically at 260 nm utilizing a NanoDrop ND-1000 (Thermofisher Scientific, Waltham, MA), the cDNA was reverse transcribed from $1 \mu \mathrm{l}$ of total RNA using the ImProm-II reverse Transcription System (Promega BioSciences, San Luis Obispo, CA) with random hexamers as transcription primers.

In order to isolate and sequence cobia $\mathrm{GH}$ from the cDNA, degenerate primers were designed over conserved gene regions in related fish, as found through the alignment of sequences from 11 different species available at GenBank (<http:// www.ncbi.nlm.nih.gov $>$ ). The degenerate primers (CobDGH- 
F1 and CobDGH-R1) used for initial gene isolation are shown in Table 1. This set of primers was used in a polymerase chain reaction (PCR) under the following conditions: $7 \mathrm{~min}$ at $94^{\circ} \mathrm{C}$ followed by 35 cycles of $94^{\circ} \mathrm{C} / 30 \mathrm{~s}, 60^{\circ} \mathrm{C} / 30 \mathrm{~s}, 72^{\circ} \mathrm{C} / 1$ min, and a final elongation step of $72^{\circ} \mathrm{C} / 7 \mathrm{~min}$, rendering a fragment of approximately $500 \mathrm{bp}$. The PCR products were separated using gel electrophoresis $(1.5 \%$ agarose containing ethidium bromide). The fragment corresponding to the expected size was extracted from the gel with a GenCatch Gel Extraction Kit (Epoch Biolabs, Sugar Land, TX) and cloned employing the PGEM $^{\circledR}$-T easy vector system (Promega). Plasmids were extracted from overnight growth cultures and DNA sequencing (The University of Texas ICMB Core Research Facilities, Austin, TX) was performed on both sense and antisense strands of the plasmid inserts of 2 clones using an ABI 3730 DNA Analyzer (Applied Biosystems, Foster City, CA). Sequences were identified and compared to those of other species using BLAST (<http://www.ncbi.nml.nih.gov>) and Vector NTI 11 software (Invitrogen, Carlsbad, CA). The sequence obtained from the partial fragment was used to design gene specific primers (CobGH-F1, CobGH-R1, and CobGH-R2) for 3' and 5' RACE using the GeneRacer ${ }^{\mathrm{TM}}$ system (Invitrogen, Carlsbad, CA, USA). In the case of the 5' RACE, it was necessary to use nested PCR to identify the PCR product. Sequences of RACE products were aligned using overlapping segments then used to design primers (CobGH-F4 and CobGH-R4) from the 5' and 3' untranslated regions (UTR) so that the entire coding sequence was contained in a single amplicon. Using these primers, GH sequences from 5 wild adult fish were compared using PCR parameters of $7 \mathrm{~min}$ at $94^{\circ} \mathrm{C}$ followed by 35 cycles of $94^{\circ} \mathrm{C} / 30 \mathrm{~s}, 60^{\circ} \mathrm{C} / 30 \mathrm{~s}, 72^{\circ} \mathrm{C} / 1 \mathrm{~min}$, followed by a final elongation step of $72^{\circ} \mathrm{C} / 7 \mathrm{~min}$.

Table 1. Degenerate and Gene-Specific primer sequences used to clone and quantify cobia GH / Secuencias de cebadores degenerados y específicos de genes utilizados para clonar y cuantificar GH cobia

\begin{tabular}{cl}
\hline $\begin{array}{c}\text { Degenerate primers } \\
\text { CobDGH-F1 } \\
\text { CobDGH-R1 }\end{array}$ & $\begin{array}{l}\text { GGGCGTGTCCTCCCARSCNATHAC } \\
\text { GGCCACGGTCAGGTAGGTYTCNACYTT }\end{array}$ \\
\hline & \\
Gene specific primers & \\
CobGH-F1 & GCAGCGTCAACTCAACAAAA \\
CobGH-F2 & TGGTGGAGTCTTGGGAGTTC \\
CobGH-F3 & AGCACGAGGACACTGAACCT \\
CobGH-F4 & GACCTGAACTGAGCCCTGAT \\
& \\
CobGH-R1 & TTCGTCTCAGCAACTCATCG \\
CobGH-R2 & TCTGGGTGAAATCTGGTTCC \\
CobGH-R3 & GACCTGAACTGAGCCCTGAT \\
CobGH-R4 & CCCTAACCCTATCATTGACGAC \\
\hline
\end{tabular}

\section{Sequence analysis}

Nucleotide sequences were compared with the GenBank nucleotide (nr/nt) database using the BLASTN algorithm (Altschul et al. 1997). AlignX (Vector NTI Software Suite 11, Invitrogen) was used to align both nucleotide and amino acid sequences. Deduced amino acid sequences were submitted to ClustalW2 (available at <http://www.ebi.ac.uk/Tools/clustalw2/ index.html >) and the phylogenetic tree was constructed using all default settings (Chenna et al. 2003). NJplot 2.1 (Perriere $\&$ Gouy 1996) was used to display the phylogenetic tree.

\section{Tissue Distribution}

Three juvenile cobia were sacrificed via a combination of MS222 (Tricaine Methanesulfonate, Argent Chemical Laboratories, Redmond, WA, USA) overdose and ice-bath immersion. This method of euthanasia has been approved by the University of Texas Institutional Animal Care and Use Committee under protocol \#07043001. Tissue samples from each fish were collected and frozen immediately on dry ice and afterwards stored at $-80^{\circ} \mathrm{C}$ until analyzed. Tissues collected included brain, pituitary, eye, gill filaments, liver, heart, stomach, spleen, gall bladder, pyloric caeca, anterior intestine, rectum, gonad, kidney, white muscle, red muscle, skin and spinal cord. Total RNA was extracted from tissue samples by homogenization in TRI Reagent ${ }^{\circledR}$-RT RNA isolation reagent (Molecular Research Center, Cincinnati, OH, USA) according to manufacturer's recommendations. Reverse transcription of the total RNA was performed using the Verso ${ }^{\mathrm{TM}}$ cDNA kit (ThermoFisher Scientific) and random hexamer primers. PCR amplification for GH was performed using GoTaq ${ }^{\circledR}$ Green Master Mix (Promega) and primers CobGH-F4 and CobGH-R4. As a control, specific primers for $\beta$-Actin mRNA (RT-ActinF1 and RT-ActinR1) developed by Tsai et al. (2008) were used with cDNA from each tissue type as well as a non-template control. The PCR parameters were the same as stated previously. Following PCR, products were separated using gel electrophoresis (1\% agarose with ethidium bromide), visualized using a UV lamp (Spectroline Bi-O-vision, Spectronics Corporation, Westbury, NY, USA) and documented using a digital camera (Kodak EDAS 290, Kodak, Rochester, NY, USA).

\section{ONTOGENY OF GH MRNA EXPRESSION IN COBIA}

For larval samples prior to the onset of exogenous feeding, larvae were collected at $0,6,12,24,36,48,60$, and $72 \mathrm{~h}$ post fertilization from 3 different spawns. For post-feeding larvae, samples were collected at 84, 204, and 300 hpf from larvae from a single egg clutch, which were reared in 4 replicate tanks 
Table 2. Size of eggs and larvae of cobia at different sampling times post fertilization. Post-hatch larvae measurements are in notochord length (NL) / Tamaño de los huevos y larvas de cobia en diferentes momentos de muestreo después de la fecundación. Mediciones en larvas eclosionadas son en longitud notocordal (NL)

\begin{tabular}{ccc}
\hline $\begin{array}{c}\text { Time } \\
(\mathrm{Hr})\end{array}$ & $\begin{array}{c}\text { Size } \\
(\mathrm{mm})\end{array}$ & $\begin{array}{c}\text { SD } \\
(\mathrm{mm})\end{array}$ \\
\hline 0 & 1.348 & 0.027 \\
6 & 1.342 & 0.025 \\
12 & 1.355 & 0.019 \\
24 & 1.359 & 0.022 \\
36 & 4.011 & 0.163 \\
48 & 4.347 & 0.250 \\
60 & 4.355 & 0.145 \\
72 & 4.612 & 0.393 \\
84 & 4.338 & 0.192 \\
204 & 5.634 & 0.927 \\
300 & 8.944 & 1.168 \\
\hline
\end{tabular}

in a recirculating system. Digital images of eggs and larvae were taken using a Wild-Heerbrugg stereomicroscope fitted with a CoolSNAP-Pro camera (Media Cybernetics, Silver Spring, MD) connected to QCapture Pro 5.0 software (Qimaging,
Burnaby, BC, Canada). Images were later processed using Photoshop 8.0 and ImageJ $1.30 \mathrm{v}$ software <http:// rsb.info.nih.gov/ij/> to ascertain egg diameter and standard lengths of larvae Table 2. Eggs ( 100 eggs) and larvae ( 20 larvae) were rinsed twice with distilled water, placed in $1 \mathrm{ml}$ of TRI Reagent ${ }^{\circledR}-\mathrm{RT}$, and frozen immediately at $-80^{\circ} \mathrm{C}$ until use. Total RNA and cDNA were obtained following the protocol described previously. Two-Step Quantitative PCR (qPCR) was performed using primers specific for $\mathrm{GH}$ (CobGH-F2 and CobGH-R1, Table 1) producing an amplicon of $219 \mathrm{bp}$. qPCR settings were $30 \mathrm{~s}$ at $95^{\circ} \mathrm{C}$ followed by 40 cycles of $30 \mathrm{~s}$ at $95^{\circ}$, $1 \mathrm{~min}$ at $55^{\circ}$, and $30 \mathrm{~s}$ at $72^{\circ} \mathrm{C}$.

\section{Results}

\section{Molecular Cloning AND SEQUenCe ANALYSIS}

PCR using degenerate primers produced an amplicon $487 \mathrm{bp}$ showing $91.4 \%$ similarity with GH from yellowtail (Seriola quinqueradiata, AAA49545). After performing RACE, the full coding sequence of the GH prohormone in cobia was deposited in GenBank (accession number GQ861507). Consistent with the phylogenetic analysis in which cobia and yellowtail were most related (Fig. 1), comparison of the GH cDNA sequence from cobia with GH from other fish species showed $86.1 \%$ similarity to GH from yellowtail.

Figure 1. Unrooted phylogenetic tree of growth hormone peptides in different fish species generated by ClustalW2 (Chenna et al. 2003) using the neighbor-joining method. The scale bar indicates the substitution rate per residue. GenBank accession numbers for the species in this alignment are: cobia (Rachycentron canadum; GQ861507), yellowtail (Seriola quinqueradiata; AAA49545), yellow perch (Perca flavescens; AY007303), Siniperca kneri (EF205281), gilthead seabream (Sparus aurata; AF195646), Nibea coibor (F)375311), snakehead (Channa striata; EF447030), Indian major carp (Cirrhinus m rigala; AF140281), Schizothorax prenanti (GQ845447), red drum (Sciaenops ocellatus; AF065165), barram undi (Lates calcarifer; LCU16816), and orange spotted grouper (Epinephelus coioides; AF376771) / Árbol filogenético sin raíz de péptidos de la hormona de crecimiento en diferentes especies de peces, generados por ClustalW2 (Chenna et al. 2003), utilizando el método de neighbor-joining. La barra de escala indica la tasa de sustitución por residuo. Los números de adhesión GenBank para las especies en esta alineación son: cobia (Rachycentron canadum; GQ861507), jurel (Seriola quinqueradiata; AAA49545), la perca amarilla (Perca flavescens; AY007303), Siniperca kneri (EF205281), dorada (Sparus aurata; AF195646), Nibea coibor (FJ375311), cabeza de serpiente (Channa striata; EF447030), carpa mayor india (Cirrhinus mrigala; AF140281), Schizothorax prenanti (GQ845447), tambor rojo (Sciaenops ocellatus; AF065165), la perca gigante (Lates calcarifer; LCU16816), y mero manchado naranja (Epinephelus coioides; AF376771) 


\section{Tissue Distribution}

Distribution of GH expression was similar in all 3 juveniles examined (Fig. 2). GH expression was found only in the pituitary, eye, gill filaments, and red muscle.

\section{ONTOGENETIC EXPRESSION}

Cobia eggs are pelagic and normally buoyant at salinities ranging from 32 to 36 and temperatures from 26 to $28^{\circ} \mathrm{C}$. The eggs were spherical, transparent and buoyant with a diameter of 1.3 $\pm 0.02 \mathrm{~mm}$ (ranging from 1.3 to $1.4 \mathrm{~mm}$ ) and a single oil droplet (diameter of $0.355 \pm 0.09 \mathrm{~mm}$ ) at the center of the egg. At 0 HPF (hours post fertilization) (Fig. 3A) the eggs had a very narrow perivitelline space and did not show cytoplasm streaming toward the animal pole, the chorion was clear and smooth with a very uniform surface. At 12 HPF (Fig. 3B), the head and segmentation of the embryo was clearly visible, while at 24 $\operatorname{HPF}$ (Fig. 3C), the embryo was nearing hatching and was fully pigmented at the tail bud stage. At this time, the heart was pumping and occasionally the embryo was twisted within the egg. After $48 \mathrm{HPF}$ the larvae did not show eye pigmentation, the vitelline sac was almost finished but the mouth was not yet open (Fig. 3G). At 72 HPF, all the larvae exhibited an opened mouth and the eyes were completely pigmented. At this time the vitelline sac was consumed and the oil droplet remained present, however, larvae appeared to be ready for the first feeding (Fig. 3I).

GH expression was low at 0 HPF $(<1000$ copies $/ \mu \mathrm{g}$ total RNA, Fig. 4) and dropped slightly during the first 12 HPF. By
$24 \mathrm{HPF}$, expression began to gradually increase until $60 \mathrm{HPF}$, when expression levels increased dramatically. By 84 HPF, GH expression reached the highest level recorded in the present study at more than 1000X the level registered at 0 HPF. By $204 \mathrm{HPF}$, expression levels dropped to approximately 100,000 copies per $\mu \mathrm{g}$ and it remained at this level through $300 \mathrm{HPF}$.

\section{Discussion}

For the first time the full-length coding sequence of the GH prohormone was cloned from adult cobia, and its distribution in different adult tissues as well as its expression in embryos and early larval stages were established. Cobia GH is similar to that of yellowtail $(86.1 \%)$ and red drum (Sciaenops ocellatus, $74.5 \%$ ), and was detected in the pituitary gland, eye, gill filaments, and red muscle. This tissue distribution is consistent with the role of $\mathrm{GH}$ in major physiological processes such as nutrient metabolism, somatic growth, and ionic balance (Reinecke et al.2005). Notably, fish in the current study did not show increased expression of GH mRNA in the gonad, which is somewhat surprising considering the important role that GH plays in reproduction (Le Gac et al. 1993), and previous work showing high expression of $\mathrm{GH}$ in the gonads of other teleosts (Dong et al. Online Early; Li et al. 2005). Fish of both sexes used in the current study were taken from a wild population during the normal spawning season so it was surprising to find such relatively low expression in the gonads, particularly in ovarian tissues.

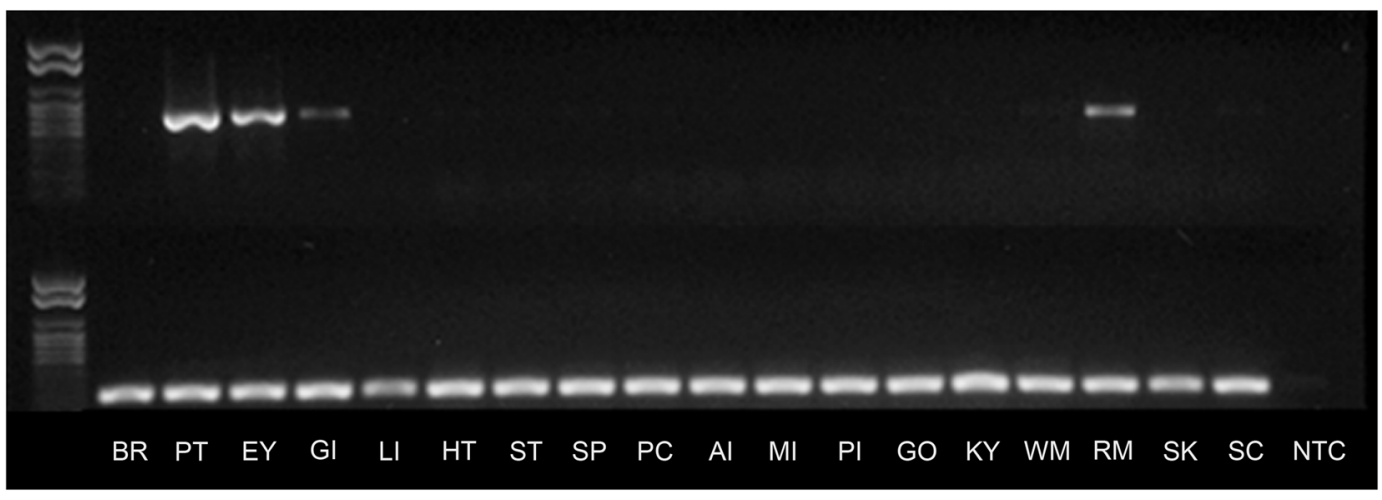

Figure 2. Tissue distribution of growth hormone mRNA in juvenile cobia (Rachycentron canadum). $\beta$-Actin was used as internal control of mRNA integrity. Brain (BR), Pituitary (PT), Eye (EY), Gill filament (GI), Liver (LI), Heart (HT), Stomach (ST), Spleen (SP), Pyloric Caeca (PC), Anterior Intestine (AI), Mid Intestine (MI), Posterior Intestine (PI), Gonad (GO), Kidney (KY), White M uscle (WM ), Red Muscle (RM), Skin (SK), Spinal Cord (SC) and No Template Control (NTC). All reactions contained the same amount of cDNA / Distribución tisular del mRNA de la hormona del crecimiento en juveniles cobia (Rachycentron canadum). $\beta$-actina se utilizó como control interno de la integridad de mRNA. Cerebro (BR), Glándula Pituitaria (PT), Ojo (EY), Filamento Branquial (GI), Hígado (LI), Corazón (HT), Estómago (ST), Bazo (SP), Ciegos Pilóricos (PC), Intestino Anterior (AI), Intestino Medio (MI), Intestino Posterior (PI), Gónadas (GO), Riñón (KY), Músculo Blanco (WM), Músculo Rojo (RM), Piel (SK), Médula Espinal (SC) y Plantilla Control (NTC). Todas las reacciones contenían la misma cantidad de ADNc 

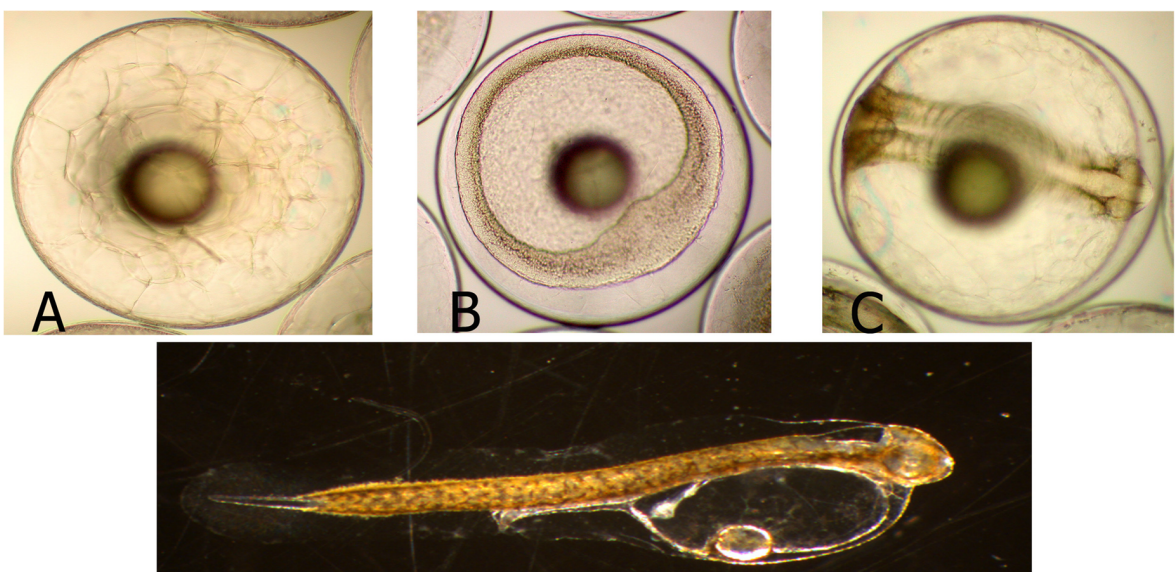

D
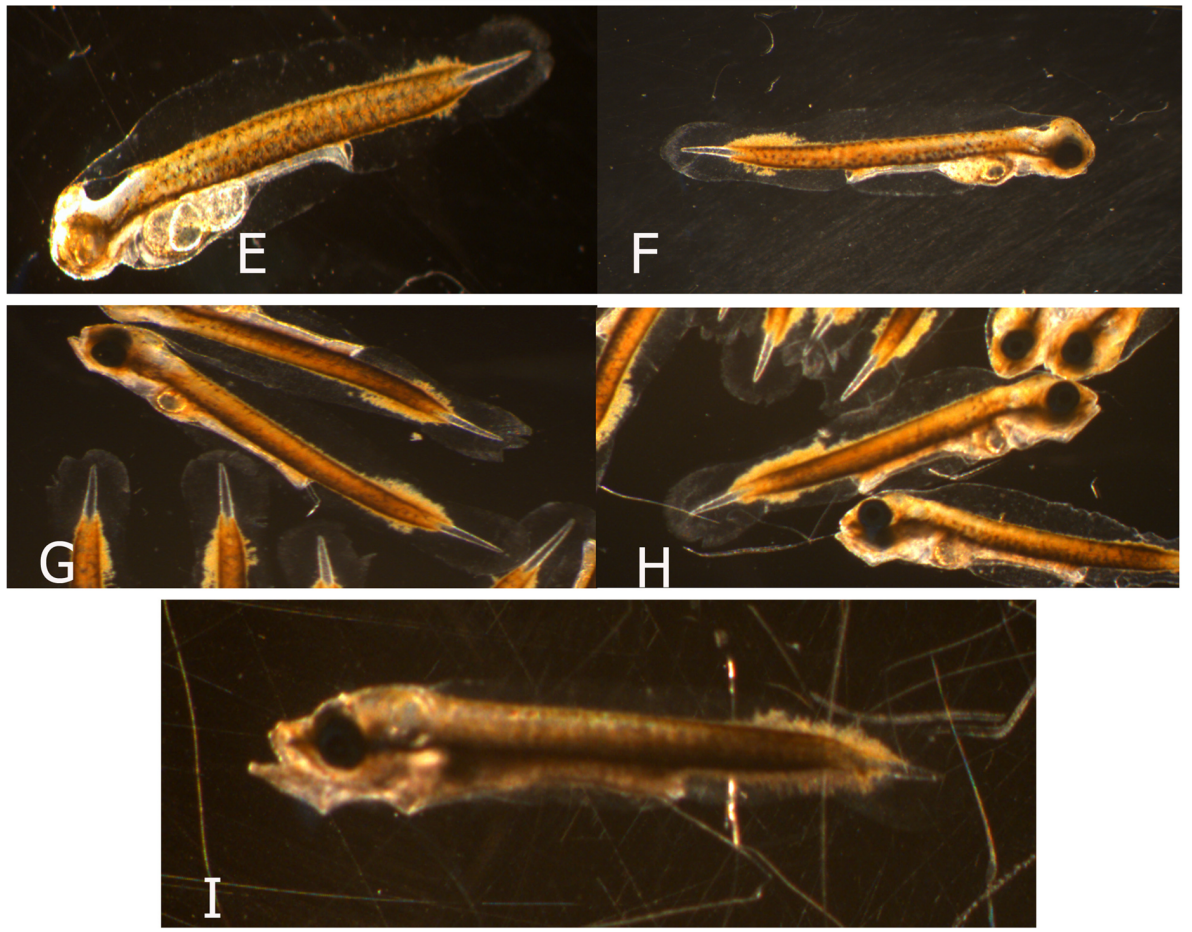

Figure 3. Fertilized cobia eggs and larvae. A) 0 hours post fertilization (HPF), B) 6 HPF, C) 12 HPF, D) 24 HPF, E) 36 HPF, F) 48 HPF, G) $60 \mathrm{HPF}, \mathrm{H}) 72 \mathrm{HPF}$ and I) 84 HPF / Huevos fertilizados y larvas de cobia. A) 0 horas post-fertilizacion (HPF), B) 6 HPF, C) 12 HPF, D) $24 \mathrm{HPF}$, E) $36 \mathrm{HPF}, \mathrm{F}) 48 \mathrm{HPF}, \mathrm{G}) 60 \mathrm{HPF}, \mathrm{H}) 72 \mathrm{HPF}$ y l) $84 \mathrm{HPF}$ 


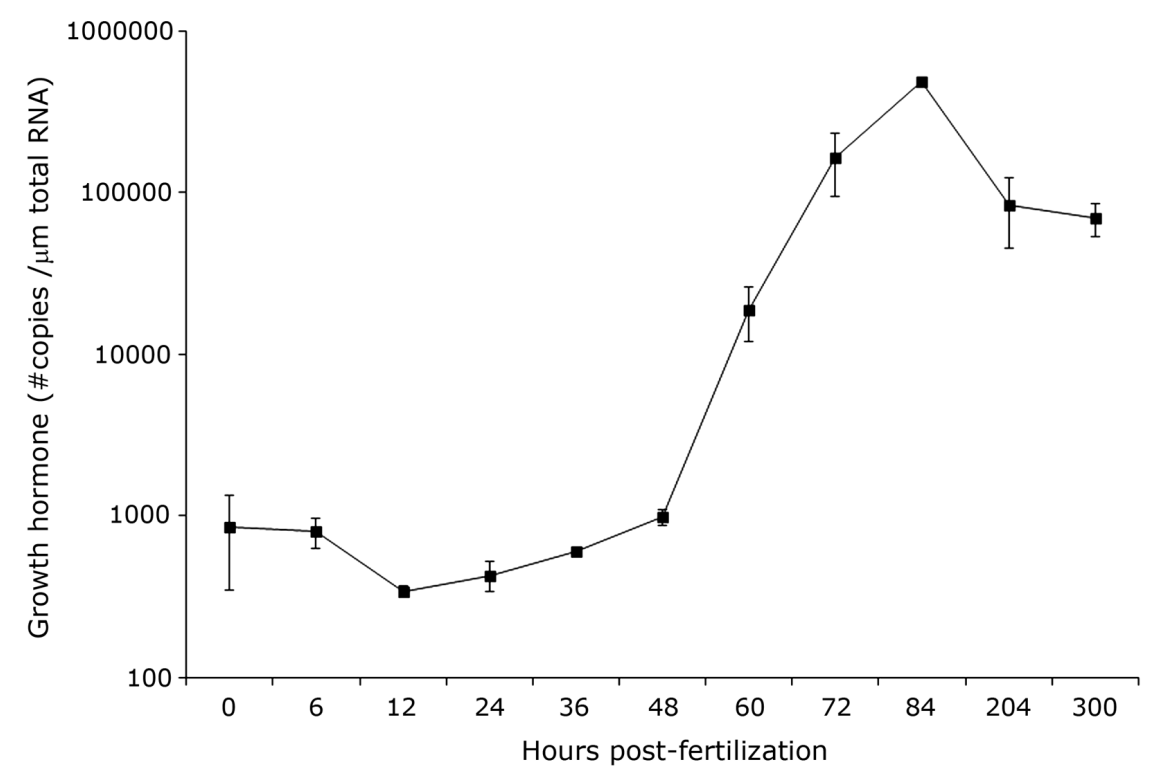

Figure 4. Expression of growth hormone mRNA in eggs and larvae of cobia. Expression was calculated using qPCR and is reported as the number of copies of growth hormone mRNA per $\mu \mathrm{g}$ of total RNA used in the reverse transcription reaction / Expresión del mRNA de la hormona del crecimiento en huevos y larvas de cobia. La expresión se calculó utilizando qPCR y se reporta como el número de copias de mRNA de la hormona del crecimiento por $\mu \mathrm{g}$ de RNA total utilizado en la reacción de transcripción inversa

GH mRNA expression in eggs and larvae began at relatively low levels with large variability at $0 \mathrm{HPF}$, increasing slightly at $24 \mathrm{HPF}$, suggesting that active transcription was occurring at this time. By 60 HPF GH expression was nearly $20 \mathrm{X}$ the initial GH levels. This dramatic increase continued through the onset of exogenous feeding at $72 \mathrm{HPF}$ and reached a peak at 84 HPF when larvae were actively feeding. This pattern is similar to that seen in silver sea bream larvae (Sparus sarba, Deane $e t$ al. 2003) and in orange-spotted grouper (Epinephelus coioides, Li et al. 2005), however the pattern is accelerated in cobia larvae.

In the present study, GH mRNA levels began to rise preceding the onset of exogenous feeding at 72 HPF while in the silver sea bream larvae the rapid increase of GH mRNA expression did not begin until 7 to 14 days after the onset of exogenous feeding. In gilthead sea bream (Sparus aurata), GH-specific mRNA was first seen at 3 days post-hatch (DPH) while the highest levels were observed at 9DPH (Funkenstein \& Cohen 1996). Increased GH expression in cobia larvae is correlated with dramatic somatic growth that occurs during this period. This is supported by the work of Ben-Atia et al. (1999) that demonstrated an early growth-promoting effect in sea bream larvae when orally administered $\mathrm{GH}$ significantly increased the growth rate.
The early onset of GH expression in cobia larvae indicates it plays an important role in early development and importantly in somatic growth. Since GH acts both directly and indirectly on somatic growth in fish (Pérez-Sánchez \& Le Bail 1999) it's early expression during larval development in cobia suggests that it might be an ideal candidate to measure nutritional condition in this species. Traditional measurements of growth during a larval studies are misinterpreted by components of the trial itself such as density-dependent growth and survival (Hitzfelder $e t$ al.2006) making it difficult to identify small differences due to treatment. Highest expression at the onset of exogenous feeding is significant given the fast growth rate of cobia larvae (Holt et al. 2007), and suggests that measurements of GH expression could be used for assessing nutrients and nutritional status of cobia larvae within a relatively short period of time.

\section{ACKNOWLEDGMENTS}

This research was partially supported by the NOAA National Sea Grant College Program Aquaculture Funds and the Perry R. Bass Endowed Chair. We would like to thank everyone at FAML, particularly Cynthia Faulk and Rick Kline, for all of their advice and technical assistance throughout the course of this project. The first author was supported by CONACYT through the 'Programa de Posdoctorado Mixto Convocatoria 2009'. This is contribution number 1711 of the University of Texas at Austin Marine Science Institute. 


\section{LITERATURE CITED}

Altschul SF, TL Madden, AA Schaffer, J Zhang, Z Zhang, W Miller \& DJ Lipman. 1997. Gapped BLAST and PSIBLAST: a new generation of protein database search programs. Nucleic Acids Research 25: 3389-3402.

Ben-Atia I, M Fine, A Tandler, B Funkenstein, S Maurice, B Cavari \& A Gertler. 1999. Preparation of recombinant gilthead seabream (Sparus aurata) growth hormone and its use for stimulation of larvae growth by oral administration. General and comparative Endocrinology 113: 155-164.

Benetti DD, B Sardenberg, A Welch, R Hoenig, MR Orhun \& I Zink. 2008. Intensive larval husbandry and fingerling production of cobia Rachycentron canadum. Aquaculture 281: 22-27.

Bolander FF. 2004. Molecular endocrinology, 632 pp. Elsevier Academic Press, Amsterdam / Boston.

Chenna R, H Sugawara, T Koike, R Lopez, TJ Gibson, DG Higgins \& JD Thompson. 2003. Multiple sequence alignment with the CLUSTAL series of programs. Nucleic Acids Research 31: 3497-3500.

Chou RL, MS Su \& HY Chen. 2001. Optimal dietary protein and lipid levels for juvenile cobia (Rachycentron canadum). Aquaculture 193: 81-89.

Craig SR, MH Schwarz \& E McLean. 2006. Juvenile cobia (Rachycentron canadum) can utilize a wide range of protein and lipid levels without impacts on production characteristics. Aquaculture 261: 384-391.

Deane EE, SP Kelly, PM Collins \& NYS Woo. 2003. Larval development of silver sea bream (Sparus sarba): Ontogeny of RNA-DNA ratio, GH, IGF-I, and Na+-K+-ATPase. Marine Biotechnology 5: 79-91.

Dong H, L Zeng, D Duan, H Zhang, Y Wang, W Li \& H Lin. 2010. Growth hormone and two forms of insulin-like growth factors I in the giant grouper (Epinephelus lanceolatus): molecular cloning and characterization of tissue distribution. Fish Physiology and Biochemistry 36: 201-212.

Faulk CK \& GJ Holt. 2003. Lipid nutrition and feeding of cobia Rachycentron canadum Larvae. Journal of the World Aquaculture Society 34:368-378.

Faulk CK \& GJ Holt. 2005. Advances in rearing cobia Rachycentron canadum larvae in recirculating aquaculture systems: Live prey enrichment and greenwater culture. Aquaculture 249: 231-243.

Faulk CK \& GJ Holt. 2006. Responses of cobia Rachycentron canadum larvae to abrupt or gradual changes in salinity. Aquaculture 254: 275-283.

Faulk CK, JB Kaiser \& GJ Holt. 2007. Growth and survival of larval and juvenile cobia Rachycentron canadum in a recirculating raceway system. Aquaculture 270: 149-157.

Funkenstein B \& I Cohen. 1996. Ontogeny of growth hormone protein and mRNA in the gilthead sea bream Sparus aurata. Growth Regulation 6: 16.
Hitzfelder GM, GJ Holt, JM Fox \& DA McKee. 2006. The effect of rearing density on growth and survival of cobia, Rachycentron canadum, larvae in a closed recirculating aquaculture system. Journal of the World Aquaculture Society 37:204-209.

Holt GJ, CK Faulk \& MH Schwarz. 2007. A review of the larviculture of cobia Rachycentron canadum, a warm water marine fish. Aquaculture 268: 181-187.

Holt GJ, KA Webb \& MB Rust. 2011. Microparticulate diets: testing and evaluating success. In: Holt GJ (ed). Larval fish nutrition, pp. 353-372. Wiley-Blackwell, John Wiley \& Sons, London.

Le Gac F, O Blaise, A Fostier, PY Le Bail, M Loir, B Mourot \& C Weil. 1993. Growth hormone (GH) and reproduction: a review. Fish Physiology and Biochemistry 11:219-232.

Li WS, D Chen, AOL Wong \& HR Lin. 2005. Molecular cloning, tissue distribution, and ontogeny of mRNA expression of growth hormone in orange-spotted grouper (Epinephelus coioides). General and Comparative Endocrinology 144:78-89.

Liao IC, TS Huang, WS Tsai, CM Hsueh, SL Chang \& EM Leaño. 2004. Cobia culture in Taiwan: current status and problems. Aquaculture 237: 155-165.

Pérez-Sánchez J \& PY Le Bail. 1999. Growth hormone axis as marker of nutritional status and growth performance in fish. Aquaculture 177: 117-128.

Perriere G \& M Gouy. 1996. WWW-query: An on-line retrieval system for biological sequence banks. Biochimie 78: 364-369.

Reinecke M, BT Björnsson, WW Dickhoff, SD McCormick, I Navarro, DM Power \& J Gutiérrez. 2005. Growth hormone and insulin-like growth factors in fish: Where we are and where to go. General and Comparative Endocrinology 142: 20-24.

Resley MJ, JKA Webb \& GJ Holt. 2006. Growth and survival of juvenile cobia, Rachycentron canadum, at different salinities in a recirculating aquaculture system. Aquaculture 253: 398-407.

Tsai ML, HY Chen, MC Tseng \& RC Chang. 2008. Cloning of peroxisome proliferators activated receptors in the cobia (Rachycentron canadum) and their expression at different life-cycle stages under cage aquaculture. Gene 425: 69-78.

Van Der Kraak G, PM Rosenblum \& RE Peter. 1990. Growth hormone-dependent potentiation of gonadotropin-stimulated steroid production by ovarian follicles of the goldfish. General and Comparative Endocrinology 79:233-239.

Wang JT, YJ Liu, LX Tian, KS Mai, ZY Du, Y Wang \& HJ Yang. 2005. Effect of dietary lipid level on growth performance, lipid deposition, hepatic lipogenesis in juvenile cobia (Rachycentron canadum). Aquaculture 249: 439-447.

Watson AM \& GJ Holt. 2010. Energy budget of early juvenile cobia, Rachycentron canadum. Journal of the World Aquaculture Society 41:224-234.

Zhou QC, ZH Wu, BPTan, SY Chi \& QH Yang. 2006. Optimal dietary methionine requirement for juvenile cobia (Rachycentron canadum). Aquaculture 258: 551-557. 